\title{
ФІЛОСОФІЯ
}

UDC 141.316 .3

O. Danilyan, Doctor of Philosophy, Professor;

O. Dzeban, Doctor of Philosophy, Professor

\section{SYNERGETIC INTERPRETATION OF SOCIETY DEVELOPMENT: CYCLICITY AND SELF-ORGANIZATION}

This article deals with the synergetic interpretation of the two cyclical theories of social development-by N. Kondratiev and by A. Chizhevsky. The idea of these conceptions that the general course of the cyclical dynamics of society does not contradict the synergetic vision of social evolution since it includes features of nonlinearity and stochasticity is grounded.

Key words: social self-organization, dissipative social processes, ordering, cyclicity.

Topicality. At the end of the XX century, the world entered an era of profound social transformation. We are witnessing that the world order, which has existed for several centuries, is collapsing and humanity is entering a new stage of its history. Its main difference is the non-linearity of the main vector of further development that can lead either to material and spiritual progress or to a global crisis that threatens the death of human civilization.

It is not surprising that in recent years social scientists have intensified discussions on further scenarios for the development of mankind. This has resulted in the recognition of the limitations of the paradigm of linear and progressive development of society and the need to substantiate new approaches that meet modern scientific achievements. For this purpose, many researchers actively use the tools of synergetics to analyse complex processes taking place in modern society. Research works on social issues that include in their epistemological apparatus basic concepts, terms and methods borrowed from synergetics have appeared. Many 
researchers consider controversial the possibility of using methodological principles developed in the natural sciences to phenomena of social nature. However, the possibility of synergetic development of methodological problems of the humanities is provided by the general scientific context - the convergence of natural and humanitarian knowledge, the migration of scientific paradigms from one branch of scientific knowledge to another.

Obviously, it is necessary to give a calm and balanced consideration to both the apparent methodological achievements of synergetics and its unreasonable claims. This involves defining the boundaries and possibilities of the functioning of the fundamental principles of synergetics.

Analysis of basic research and publications. In the modern social science, many research works have been devoted to synergetics. The basic ideas of synergetics, as we know, are set forth in the works by R. Keller, G. Nikolis, I. Prigozhin, I. Stengers, H. Haken, E. Yantsch, and also in the studies of Russian scientists V. Arshinov, V. Budanov, Yu. Danilov, K. Delokarov, S. Kapitza, S. Kurdyumov, G. Malinetsky, N. Poddubny, V. Ratnikov, A. Rudenko, Ya. Svirsky and others.

The possibilities of using the synergetic approach in social and human sciences in general were described in the studies by E. Antonov, V. Volov, V. Egorov, D. Kitaev, A. Kokin, E. Kniazeva, V. Lutai, V. Stepin, N. Talanchuk, M. Shterenberg, etc. Some aspects of the methodological problems of the use of synergetics in the humanities were analysed by L. Barausova, V. Voitsekhovich, I. Dobronravova, A. Kezina and E. Laslo.

The formation of a special layer of synergetic research related to the problems of social and humanitarian knowledge is of particular importance for our study. Among the representatives of social synergetics, which promotes the spread of synergetic ideas in social philosophy, A. Astafieva, A. Borzykh, V. Bransky, V. Kapustin, A. Kozlova, A. Kotelnikov, A. Muzyka, S. Pozharsky, N. Savichev and others can be mentioned.

The unusual popularity of synergetic ideas and generally uncritical use of the categorical apparatus of synergetics in various fields of knowledge cause experts well-founded fears that the methodological significance of synergetics will be lost. However, there are reasons to believe that the use of synergetics in the study of social and cultural processes demonstrates the search for an integral worldview concept that requires a rethinking of the accumulated spiritual and intellectual experience [1-7]. There are prerequisites for a new synthesis of the fundamental science, philosophy and religion, the combination of physics and metaphysics. It brings us closer to the formation of a new worldview based on modern scientific principles.

The main research material. One of the most productive areas in this context is the synergetic interpretation of social cycles of self-organization that arise as 
a consistent development of the logic of various phases of ordering social systems inherent in the very nature of these systems. This approach shows a synergetic understanding of order as a process which has different laws of structural changes in the system at different phases.

The methodological reference point for this interpretation is the description provided by A. Knyazev and S. Kurdyumov of various modes of complex nonlinear systems in the process of their self-organization such as LS-mode and HS-mode [8]. Considering the interpretation of structural and evolutional changes of complex systems in general scientific conceptions (cybernetics, general systems theory, etc.), these modes can be defined as a mode of order generation and a mode of maintaining order in a single cycle of self-development of social systems.

The first type of the system functioning is characterized by the processes described in synergetics as order formation processes: the dominance of the nonentropic factor over the entropic factor, the sensitivity to fluctuations at the micro level, the growth of heterogeneity and diversity in the structure, violation of the primary symmetry, the tendency to chaos at the macro level, the growing intensity of processes, etc. The second type is characterized by the processes that ensure its preservation and stable existence: the dominance of the dissipative factor, low sensitivity to fluctuations at the micro level, erosion of inhomogeneities and strengthening of homogeneity in the structure, a decrease in the intensity of processes and others.

In order to reveal these patterns in social phenomena and processes, it is necessary to develop a system of social indicators of the manifestation of various aspects and phases of the process of social self-organization. In general, the following factors can be considered as such indicators.

On the one hand, the tendency for order generation in social systems is characterized by such processes as the strengthening of social metabolism in the resource, economic, information and cultural spheres; the growth of social heterogeneity and differentiation; the growth of chaos at the macro level of the social system as a consequence of social dynamics (crisis phenomena in the economy, politics, etc.); the growth of crime; strengthening democratic principles in the political and public sphere; the domination of ideas and values of liberalism in the ideological and political terms, etc.

On the other hand, the tendency to maintain order in social systems is characterized by a transition to their more closed state; establishment of authoritarian and totalitarian regimes as the only hierarchical centre of power; the dominance of conservative ideologies and values of traditional culture and morality which are understood as essentials for stability and so on. 
The alternation of the two trends indicated above is a general algorithm for various cyclical theories. Thus, the descriptions in cyclical theories of the stages of order generation and stages of maintaining order consecutively correspond to: in the theory of long waves of economic conditions by N. Kondratiev - the upward wave (the rising phase) and the downward wave (the decay phase) [9]; in the theory of political cycles by A. Schlesinger, Jr. - the phase of public purposefulness of political life and the phase of orientation toward private interests [10]; in the theory of cycles of sociocultural dynamics by S. Maslov - analytical («left hemisphere») and synthetic («right hemisphere») periods of social perception of the world [11]; in the theory of the influence of solar activity on the social dynamics by A. Chizhevsky - periods of intensification and weakening of excitability of solar activity [12], etc.

We briefly dwell on the synergetic interpretation of only two of the listed theories the theories by N. Kondratiev [9] and by A. Chizhevsky [12]. The choice of these theories can be described by the fact that they are the most representative in terms of the analysed empirical data, and also because they carry out a deep interdisciplinary synthesis of the influence of various factors on the cyclical dynamics of society (N. Kondratiev deals with economic, political, social and psychological indicators; A. Chizhevsky analyses bio-psychological, historical and social factors).

The synergetic interpretation of long waves of economic situation by N. Kondratiev can be summarized as follows. The processes that characterize the beginning of the economic recovery phase, described by N. Kondratiev, are compared with the characteristics of a more open existence of an economic system, the strengthening of social metabolism, both external (expansion of foreign economic contacts) and internal (free flow of capital). This condition is characterized by high dynamism: weak depressions, intensive upsurge, the creation of productive forces that change the structure of economic ties and the system of relations established between owners. The emergence of new growth points (new industries, enterprises, entrepreneurs that grow rich) gives rise to structural heterogeneity and, consequently, instability. The struggle for spheres of influence in the domestic market and class struggle are intensifying. Revolutions of redistribution grow in favour of a new economic vanguard, which is especially possible on the crest of a rising wave (near the point of bifurcation).

The energy of economic activity spent on internal and external struggle begins to fade. The dissipative process slows down the general rate of development, there comes a long depression or crisis (the phase of the recession), which cannot be reversed by the bursts of economic activity that arise during this period. The number of foreign economic contacts is reduced. Restrictions of systemic metabolism and loss of the main impulse of development give rise to specific structural 
transformations. There is an accumulation of capital for future growth points. The low dynamism in the development of production secures people in their social niches, the claims of the class struggle weaken, which leads to the preservation of the existing economic situation.

The system begins to save power on the order. The structure, formed by creating the potential for a difference in its «new order», generates its own internal imbalance, directing the previously diverged subsystems towards each other. There is a new wave of internal metabolism, which, as N. Kondratiev states, is indivisible from external metabolism: a period of new entrepreneurial activity is beginning - the beginning of a new economic cycle.

Thus, the synergetic interpretation of N. Kondratiev's theory makes it possible to identify it as a developed model of social self-organization in the economic sphere with a successive alternation of the stages of order generation and the stages of maintaining order. This approach is supplemented, extended and specified by V. Vasilkova in a number of publications $[13 ; 14$, etc.]

Analysing the conception of A. Chizhevsky of the cycles of solar activity and its impact on social activity, we can also find in it, with a certain logical reconstruction, an analogy of the synergetic description of the universal process of self-organization of complex systems. The emergence of a new social order can be attributed to the period of increasing solar activity, which is the energy source of a special psychophysical state of mass excitability, which has objectified in a certain type of social behaviour. If the previous stage of the minimum solar activity was characterized by the disunity of the masses, their indifference to political and other issues, tolerance, then the birth of new structural relations is accompanied by «collective concentration,» the grouping of ideas and masses around individual leaders and parties. These processes correspond to the necessary effects of selforganization - the appearance of heterogeneity in the structure and the emergence of coherence of the elements of the system around the centres of heterogeneity.

In the period of maximum solar activity, the tendency, emerged at the previous stage, unfolds to the fullest extent - the critical processes of new structures formation take place. The activity of the sun creates a powerful energy imbalance, a sharp increase in nervous-psychic excitability of the masses is observed, which generates strong reactions even to weak stimuli. According to A. Chizhevsky, during this period, sometimes one word said in time or gesture is enough to set in motion armies and peoples. This social situation correlates with the description of the synergetic effect of resonant excitation in the process of order generation.

The speed (dynamics) arising at this time and the width of the territorial coverage of the mass action, mentioned by A. Chizhevsky, are very similar to the synergetic characteristics of the regime with exacerbation and the emergence of new structures 
in conditions of imbalance. The heterogeneity, which increases, manifests itself as «chaos at the macro level,» the struggle between different centres of heterogeneity. According to A. Chizhevsky, this period promotes the maximum development of the parliamentary system, democratic and social reforms, rebellions, revolutions, wars and so on.

The period of the fall of solar activity is characterized by the onset of a depressive psychophysical state; the general need for peace is felt; the pace of events slows down. Social intransigence is replaced by indifference, existing political and military alliances break up, people's assemblies are easily dispersed, insurrections are suppressed. There are features and signs characteristic of the establishment of a synergetic regime of self-preservation of structures - of the completion of another cycle of self-organization.

When using the synergetic interpretation of cyclical processes in social evolution, we inevitably face a fundamental methodological contradiction that must be solved for the further development of this research approach, namely: how does the logic of cyclical development correlate with its rigid periodicity, with the nonlinear character of social evolution? Thus, a problem arises the most significant aspects of which, in our opinion are the following. Firstly, the cyclical dynamics of social development is largely determined by the open nature of systems that can be responsive to changes in the environment that is represented by natural biological components whose development is cyclical. With this understanding, social cycles act as a way of adapting society to the natural environment.

Secondly, cyclical dynamics does not exclude spontaneous and stochastic development, just as in the synergetic interpretation the order at the macro level does not exclude chaos at the micro level. Cycles are particularly accurate at macro levels, but if to consider similar patterns at lower levels, significant deviations from the general dynamics are possible.

Thirdly, the very trajectory of the social cycle has both bifurcation zones of stochastic choice and stable areas of development when the tendency for selfstructuring develops consistently.

Fourthly, the nonlinear nature of the social environment makes the cyclical dynamics so asynchronous that the picture of the development of the social system appears generally as multi-vector and difficult to predict. After all, cyclical processes, as relevant studies show, have essential characteristics, different manifestations in various social spheres, as well as different oscillatory amplitudes.

Conclusions. Thus, summarizing, we should note that the general course of the cyclical dynamics of society, revealed in the relevant conceptions, does not contradict the synergetic vision of social evolution, since together with the features of determinism and predictability it includes the features of nonlinearity, 
stochasticity and unpredictability. In this regard, the prospects for the study of the cyclical processes of social self-organization will obviously be related not only to the solution of the problem whether it is possible to compare the different periodicity of cycles in various spheres of social life, but mainly whether it is possible to compare the influence of various determinants of social evolution, and it leads us to the problem of interdisciplinary synergetic research.

\section{BIBLIOGRAPHY}

1. Буданов В. Г. Методология синергетики в постнеклассической науке и в образовании : монография / В. Г. Буданов. - [Изд. 2-е, испр.]. - M. : URSS. ЛКИ, 2008. $230 \mathrm{c}$.

2. Вагурин В. А. Синергетика эволюции современного общества / В. А. Вагурин. Луганск : Копицентр, 2005. - 200 с.

3. Синергетика в науке и наука языком синергетики : [сб. ст.]. - Одесса : Астропринт, 2005. - $181 \mathrm{c}$.

4. История и синергетика: математическое моделирование социальной динамики / [С. Ю. Малков (отв. ред.), А. В. Коротаев (отв. ред.)]. - М. : КомКнига, 2005. - 191 с.

5. Снегірьов І. О. Роль еволюційно-синергетичної парадигми в осмисленні соціуму : автореф. дис. ... канд. філос. наук : 09.00.09 / І. О. Снегірьов. - Київ, 2005. $16 \mathrm{c}$.

6. Малинецкий Г. Г. Нелинейная динамика. Подходы, результаты, надежды / Г. Г. Малинецкий, А. Б. Потапов, А. В. Подлазов. - М. : URSS. КомКнига, 2006. - 279 с.

7. Данильян О. Г. Циклічність і самоорганізація у розвитку соціуму / О. Г. Данильян, О. П. Дзьобань // Гілея : наук. вісн. : зб. наук. пр. / голов. ред. В. М. Вашкевич. Київ : ВІР УАН, 2011. - Вип. 47. - С. 214-220.

8. Князева Е. Н. Законы эволюции и самоорганизации сложных систем / Е. Н. Князева, С. П. Курдюмов. - М. : Наука, 1994. - 229 с.

9. Кондратьев Н. Д. Большие циклы конъюнктуры и теория предвидения / Н. Д. Кондратьев. - М. : Экономика, 2002. - 765 с.

10. Шлезингер А. М. Циклы американской истории / А. М. Шлезингер ; [пер. с. англ. П. А. Развина, Е. И. Бухаровой ; заключ. ст. В. И. Терехова]. - М. : Прогресс : Прогресс-академия, 1992. -685 с.

11. Маслов С. Ю. Теория дедуктивних систем и ее применение / С. Ю. Маслов. - М. : Радио и связь, 1986. - 135 с.

12. Чижевский А. Л. Космический пульс жизни / А. Л. Чижевский ; [сост., вступ. ст., коммент. Л. В. Голованова]. - М. : Мысль, 1995. - 766 с.

13. Волновые процессы в общественном развитии / [В. В. Василькова, И. П. Яковлев, И. Н. Барыгин и др.]. - Новосибирск : Изд-во Новосиб. ун-та, 1992. - 227 с.

14. Василькова В. В. Порядок и хаос в развитии социальных систем: Синергетика и теория социальной организации / В. В. Василькова. - СПб. : Лань, 1999. $478 \mathrm{c}$. 


\title{
REFERENCES
}

1. Budanov V. G. (2008). Metodologiya sinergetiki v postneklassicheskoy nauke i v obrazovanii. Moscow: URSS. LKI [in Russian].

2. Vagurin V. A. (2005). Sinergetika evolyutsii sovremennogo obschestva. Lugansk: Kopitsentr [in Russian].

3. Sinergetika v nauke i nauka yazykom sinergetiki. (2005). Odessa: Astroprint [in Russian].

4. Istoriya i sinergetika: matematicheskoe modelirovanie sotsialnoy dinamiki. S. Yu. Malkov (Ed.), A. V. Korotaev (Ed.). (2005). Moscow: KomKniga [in Russian].

5. Snehirov I. O. (2005). Rol evoliutsiino-synerhetychnoi paradyhmy v osmyslenni sotsiumu. Extended abstract of candidate's thesis. Kyiv [in Ukrainian].

6. Malinetsky G. G. (2006). Nelineynaya dinamika. Podhody, rezultaty, nadezhdy. Moscow: URSS. KomKniga [in Russian].

7. Danilyan O. H. (2011). Tsyklichnist i samoorhanizatsiia u rozvytku sotsiumu. [Cyclicity and Self-organization of Society Development]. Hileia. V. M. Vashkevych (Ed.), issue 47, 214-220 [in Ukrainian].

8. Knyazeva E. N. (1994). Zakony evolyutsii i samoorganizatsii slozhnyh sistem. Moscow: Nauka [in Russian].

9. Kondratiev N. D. (2002). Bolshie tsikly kon'yunktury i teoriya predvideniya. Moscow: Ekonomika [in Russian].

10. Shlezinger A. M. (1992). Tsikly amerikanskoy istorii. Moscow: Progress: Progressakademiya [in Russian].

11. Maslov S. Yu. (1986). Teoriya deduktivnih sistem i ee primenenie. Moscow: Radio i svyaz [in Russian].

12. Chizhevsky A. L. (1995). Kosmicheskiy puls zhizni. Moscow: Mysl [in Russian].

13. Volnovye protsessy v obschestvennom razvitii. V. V. Vasilkova, I. P. Yakovlev, I. N. Barygin et al. (1992). Novosibirsk: Izd-vo Novosib. un-ta [in Russian].

14. Vasilkova V. V. (1999). Poryadok i haos v razvitii sotsialnyh sistem: Sinergetika i teoriya sotsialnoy organizatsii.

\section{СИНЕРГЕТИЧЕСКАЯ ИНТЕРПРЕТАЦИЯ РАЗВИТИЯ ОБЩЕСТВА: ЦИКЛИЧНОСТЬ И САМООРГАНИЗАЦИЯ}

\author{
Данильян О. Г., Дзебань А. П.
}

Эта статья посвящена синергетической интерпретации двух ииклических теорий развития общества - Н. Кондратьева и А. Чижевского. Обосновывается идея, что общий ход ииклической динамики общества, обнаруженный в этих конщепщиях, не противоречит синергетическому видению сочиальной эволюиии, поскольку включает в себя моменты нелинейности и стохастичности.

Ключевые слова: общественная самоорганизация, диссипативные социальные процессы, упорядочение, чикличность. 


\title{
СИНЕРГЕТИЧНА ІНТЕРПРЕТАЦІЯ РОЗВИТКУ СУСПІЛЬСТВА: ЦИКЛІЧНІСТЬ І САМООРГАНІЗАЦІЯ
}

\author{
Данильян О. Г., Дзьобань О. П.
}

Ця стаття присвячена синергетичній інтерпретації двох иүклічних теорій розвитку суспільства - М. Кондратьєва й О. Чижевського.

Обтрунтовується авторська позиія, щзо активне застосування синергетики до дослідження сочіокультурних прочесів свідчить про пошук иілісного світоглядного концепту пояснення світу, щуо вимагає переосмислення накопиченого духовного та інтелектуального досвіду. Виникають передумови нового синтезу фундаментальної науки, філософії і релігії, з'єднання фізики й метафізики, щяо наближає до формування нового світобачення на сучасних наукових засадах.

Показано, щуо одним із найбільш плідних напрямів у цуьому сенсі є синергетична інтерпретачія сочіальних ичиклів самоорганізації, які постають як послідовне розгортання логіки різних фаз упорядкування соиіальних систем, іманентно властивої самій природі иих систем. У такому підході втілюється синергетичне розуміння порядку як прочесу, на різних фазах якого діють різні закони структурних змін у системі.

Доказується, що методологічним орієнтиром для такого кщталту інтерпретації може слугувати опис різних режимів існування складних нелінійних систем у прочесі їх самоорганізаиї - LS-режиму й HS-режиму, наведений О. Князєвою й С. Курдюмовим. У сполученні з тлумаченням структурно-еволюиійних змін складно організованих систем у загальнонаукових конщепціях (кібернетиці, загальній теорії систем тощо) иі режими можуть бути позначені як режим зародження порядку и режим збереження порядку в єдиному ииклі саморозвитку соціальних систем.

Обтрунтовується, що послідовно опису етапів зародження порядку й етапів збереження порядку в ииклічних теоріях відповідають: у теорії довгих хвиль економічної кон'юнктури М. Кондратьєва - підвищувальна хвиля (фаза підйому) і понижувальна хвиля (фаза спаду); у теорії політичних ииклів А. Шлезінгера-молодшого фаза суспільної иілеспрямованості політичного життя й фаза орієнтації на приватні інтереси; у теорії ииклів соціокультурної динаміки С. Маслова - аналітичний («лівопівкульний») і синтетичний («правопівкульний») періоди соціального світосприйняття; у теорії впливу сонячної активності на соџіальну динаміку О. Чижевського - періоди посилення й послаблення збудливості сонячної активності тощо.

Розгляд у статті основних положень конщепиії М. Кондратьєва й О. Чижевського дозволив зробити висновок, щзо загальний перебіг циклічної динаміки суспільства, виявлений у циих концепціях, не суперечить синергетичному баченню сочіальної еволючії, оскільки містить у собі моменти нелінійності й стохастичності.

Ключові слова: суспільна самоорганізачія, дисипативні сочіальні прочеси, упорядкування, циклічність.

\section{$\operatorname{son} 2$}

